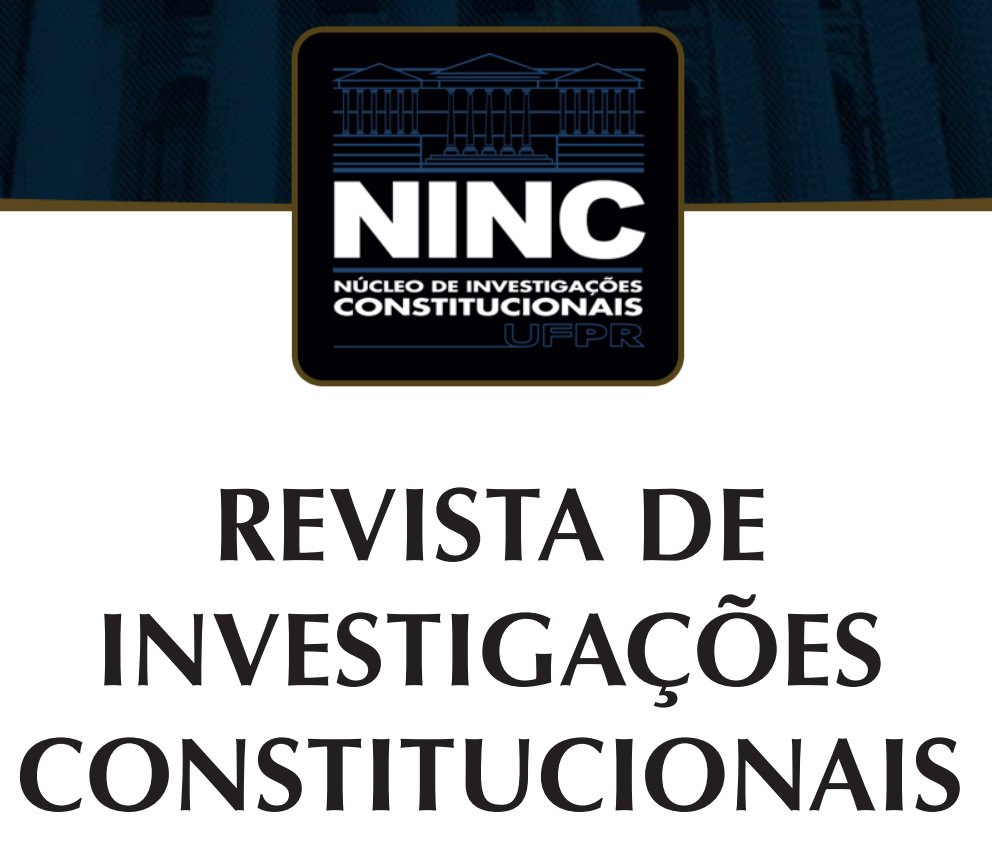

JOURNAL OF CONSTITUTIONAL RESEARCH

vol. 5 | n. 3 | setembro/dezembro 2018 | ISSN 2359-5639 | Periodicidade quadrimestral Curitiba | Núcleo de Investigações Constitucionais da UFPR | www.ninc.com.br 


\section{Making Brazil work? Brazilian coalitional presidentialism at 30 and its post-Lava Jato prospects}

\section{Fazendo o Brasil funcionar? O presidencialismo de coalizão brasileiro aos seus 30 anos e suas perspectivas pós-Lava Jato}

Abstract

This article analyzes the topic of Brazilian coalition presidentialism. It offers the reader a close look at coalitional presidentialism in each of Brazil's governments since the democratization of the country to the present day, presenting the complex relations between the Legislative Branch and the Executive Branch at these different moments in Brazil's political history. The main focus of the article is to relate the impacts of "Lava Jato" to this process, seeking to indicate possible consequences of this operation, which caused great repercussions on Brazilian politics, to this scenario of the relationship between the Executive and Legislative branches.

Keywords: coalitional presidentialism; Brazil; democratization; Lava Jato; Brazilian Constitution

\section{ANDREA SCOSERIA KATZ}

Yale University (United States of America) andrea.s.katz@gmail.com

Recebido/Received: 12.08 .2018 / August $12^{\text {th }}, 2018$ Aprovado/Approved: 03.09.2018/September 03 ${ }^{\text {rd }}, 2018$

Resumo

O artigo analisa a questão do presidencialismo de coalizão nos países da América Latina em geral e no Brasil em particular. Oferece ao leitor um olhar mais atento ao presidencialismo de coalizão em todos os governos brasileiros desde a democratização do país até os dias atuais, apresentando as complexas relações entre o Poder Legislativo e o Poder Executivo nesses diferentes momentos da realidade política brasileira. O principal foco do artigo é relacionar os impactos da operação "Lava Jato" a esse processo, buscando indicar possíveis consequências desta operação, que causou grandes repercussões na política brasileira, a esse cenário de relacionamento entre os Poderes Executivo e Legislativo.

Palavras-chave: presidencialismo de coalizão; Brasil; democratização; Lava Jato; Constituição brasileira.

Como citar esse artigo/How to cite this article: KATZ, Andrea Scoseria. Making Brazil work? Brazilian coalitional presidentialism at 30 and its post-Lava Jato prospects. Revista de Investigações Constitucionais, Curitiba, vol. 5, n. 3, p. 77-102, set./dez. 2018. DOI: 10.5380/rinc.v5i3.60965.

"Ph.D. in Political Science at Yale University (New Haven, United States of America). J.D. at Yale Law School (New Haven, United States of America). Currently a clerk at the U.S. federal court in Massachusetts, and previously a Robina Human Rights Fellow at the European Court of Human Rights in Strasbourg, as a clerk for Judge András Sajó (Hungary), Vice-President of the Court. E-mail: andrea.s.katz@gmail.com. 


\section{CONTENTS}

1. Introduction; 2. Coalitional Presidentialism: Efficiency and Accountability at Loggerheads; 3. Accountability: Mechanisms of Presidential Oversight; 4. A Balance Sheet for Coalitional Presidentialism; 5. In Lava Jato's Wake: The Semi-Presidential Temptation and Lasting Changes?; 6. References.

\section{INTRODUCTION}

In 1865, British constitutional theorist Walter Bagehot memorably explained that the success of British government lay in "the efficient secret" of its Constitution, which mandates "the nearly complete fusion of the executive and legislative powers." By the end of the nineteenth century, cabinet government, as we call it today, had transformed a once-fractious House of Commons. Party interests trumped those of the individual MP or borough; programmatic policymaking replaced incoherent pork-barrel spending; and Parliament on the whole grew more productive, rising to the task of governing a newly modernizing and modern Britain. ${ }^{2}$

By this yardstick, it is not a terrible exaggeration to say that the Brazilian Constitution of 1988 harbors a very inefficient secret. The virtues Bagehot praised are replaced by their opposite. Brazil's legislature, widely regarded as a "cesspit of venality and opportunism," is famously weak in governing, more active in the business of distributing pork barrel than on national issues. ${ }^{3}$ The party system is weak-twenty-six different parties currently hold seats in Brazil's Chamber of Deputies, thirty-five officially registered with the Superior Electoral Court (TSE), and opportunistic party-switching among legislators is legion. ${ }^{4}$ With no ready-made majorities and scant party discipline, temporary legislative coalitions are stitched together with pork, by baiting legislators with Cabinet portfolios, or, more crudely, through sheer bribery. ${ }^{5}$

\footnotetext{
${ }^{1}$ Walter bagehot, quoted in KELLY, Scott. The slow death of the 'Efficient Secret': The Rise of MP independence, its causes and its implications. London: The Constitution Society, 2014, p. 6.

${ }^{2}$ COX, Gary. The Efficient Secret. New York: Cambridge University Press, 1987, esp. Chapter 6. KELLY, supra, describes a breaking down of the close relationship in such a way as to precisely bolster Cox's theory: "The weakening of the party system and the rise of MP independence is also making it increasingly difficult to reconcile the dual functions of a vote cast at a general election - to choose an MP and a Party of Government. The result is a growing accountability gap."

${ }^{3}$ ANDERSON, Perry. Lula's Brazil. London Review of Books, vol. 33, no. 7, p. 3-12, Mar. 31, 2011; AMES, Barry. Electoral Rules, Constituency Pressures, and Pork Barrel: Bases of Voting in the Brazilian Congress. Journal of Politics, vol. 57, no. 2, p. 324-343, 1995, 324; AMES, Barry. The Deadlock of Democracy in Brazil. Ann Arbor: University of Michigan Press, 2002.

${ }^{4}$ DESPOSATO, Scott. Party Switching in Brazil: Causes, Effects, and Representation. In: HELLER, William B.; MERSON, Carol (eds.). Political Parties and Legislative Party Switching. New York: Palgrave Macmillan, 2009, p. 109-44. Until recently, it was common for politicians to switch parties, thereby changing the composition of the chambers and destabilizing legislative coalitions. However, in 2007, the Supreme Federal Court put a stop to the practice of party switching after elections, reasoning that legislative seats belong to parties, not to individuals.

${ }^{5}$ The "Mensalão" was the name of the scandal that broke in 2005 when word got out that Lula's Workers Party (PT) was doling out monthly payments of $\$ 7000$ to representatives in exchange for their votes. Today, in the light of its larger cousin, Lava Jato, however, the Mensalão has come to seem like small potatoes.
} 
Dating back to the mid-twentieth century, the coalitional presidential system was described in 1949 by the Brazilian legal scholar Afonso Arinos as "unique in the world," its leaders more like "those of European parliamentarism than the president of the United States." ${ }^{\prime 6}$ Since then, generations of scholars have waffled back and forth as to whether this unique arrangement is a good thing. After the constitution of 1988, a first generation of scholars was pessimistic. Brazil's institutions were untested and seemingly weak, hyperinflation was ravaging the economy, and the first few administrations were plagued by corruption scandals. A second generation-buoyed by robust growth under Fernando Henrique Cardoso and Lula-spoke of the "unexpected success" of Brazil's coalitional presidential regime. Today, of course, the mood has swung back to gloom, with the massive Lava Jato investigation exposing the system's rotten foundations.

As is clear, scholars' assessments of the system are often tied to the state of Brazilian politics at the time they are writing, which casts some doubt on the durability of the conclusions, and they often boil down to one, unasked premise: what is the real cost of coalition formation? If coalitions could be bought with ideological cohesion (as in two-party systems), coalitional presidentialism was relatively cheap, and thus a viable model. If the cost of coalitions was pork barrel, the system's flaws became harder to defend, but it could still allow for good outcomes where a strong, capable President was there to bind things together. If the whole thing depended on corruption, however, as Lava Jato has seemed to prove, the only possible conclusion would be deep pessimism.

This paper argues that said debate is one-sided, because it typically omits the critical role played in this system by the judiciary — courts and prosecutors. ${ }^{7}$ If Lava Jato has taught us anything, it is, first, just how deep corruption ran in "making the system work" and, second, how essential is the role of the judiciary in mediating ordinary politics. In this light, I argue that Brazil's "inefficient secret" is its combination of a weak party system and a judicialized politics. The former virtually guarantees that non-programmatic tools like pork have been, and will continue to be, the mortar binding legislative majorities together, and that Congress will lack the energy to act against the President, the crucial actor creating legislative majorities and moving them to action. On the other hand, in light of Congress' weakness, political oversight requires the conspicuous and public participation of the judiciary. Not limited to just Lava Jato, the judiciary's political role is so developed that it is essential in shaping party balance, and even the content of policy. This alone could be a problem, but it is the clash of judicial norms (probity, pu-

\footnotetext{
${ }^{6}$ Afonso Arinos, quoted in MELO, Marcus André; PEREIRA, Carlos. Making Brazil Work: Checking the President in a Multiparty System. New York: Palgrave Macmillan, 2013. p. 4.

${ }^{7}$ I am aware that under the Brazilian Constitution, the Ministério Público (the Public Prosecutor's Office) is an independent body subject to the control of neither the Executive Branch nor the judicial branch. However, I describe it as exercising a "judicial" function because its primary tools-lawsuits and investigations-and the norms it obeys and imposes are themselves juridical.
} 
blicity, and transparency) with a legislative process built under precisely the opposite expectations (compromise, quid pro quo, pork) that is truly unmanageable.

First, I describe the basics of Brazil's coalitional system, framing these in terms of two competing imperatives: efficiency and accountability. Every governing system requires efficiency to run, but for Brazil, with its fragmented party system, the costs are uniquely high. Accountability, on the other hand, is achieved not by a robust Congress and President vying against each other, but by court oversight, and with it norms that call into question the very system of coalition government. Second, I turn to the normative, canvassing scholarly assessments of the system before offering my own. Finally, I offer a few tentative ideas on what lasting effect Lava Jato and other recent shocks to the system (electoral reform, proposals to adopt a semi-presidential system) promise to have.

There is no doubt that Lavo Jato-fatigue has already set in among most Brazilians, and the pace of arrests will slow as the system approaches something like normalcy. Still, the built-up furor does not seem to have been channeled into institutional reforms that will remedy the system's problems. Proposed party and electoral reforms are unlikely to completely rationalize Brazil's political parties; legislative majorities are likely to remain ad hoc and pork-based; and even the instauration of a prime minister, should that reform eventually pass (unlikely given the weakness of Temer, an interim president), is unlikely to staunch the need for judicial interventions to police system functioning. As a result, fits and starts, rather than growing pains, seem likely to characterize Brazil's politics for years to come.

\section{COALITIONAL PRESIDENTIALISM: EFFICIENCY AND ACCOUN- TABILITY AT LOGGERHEADS}

With an idea in mind of tyranny as "the accumulation of all powers in the same hands, whether of one, a few, or many," James Madison and his co-drafters created the blueprint for the world's first presidential republic. Splitting up the king's power to make the law from the power of enforcing it, they created a regime of cleverly engineered separations - the president from the legislature, the legislature into multiple bodies, the body politic into regional and local units. ${ }^{8}$ At the same time, as they knew from the failure of the 1777 Articles of Confederation, which had required unanimity

\footnotetext{
${ }^{8}$ On the republicanism of the American Founding Fathers, the classic accounts are provided by BAILYN, Bernard. The Ideological Origins of the American Revolution. Cambridge, MA: Harvard University Press, 2017. and WOOD, Gordon S. The Creation of the American Republic, 1776-1787. Chapel Hill, NC: University of North Carolina Press, 1998.
} 
among the thirteen original states for all resolutions, the greater the number of actors involved in decision-making, the greater the risk of paralysis. ${ }^{9}$

The Framers' problem illustrated the basic challenge of designing a presidential system: how, in the name of active government, to stimulate cooperation between actors that the constitution separates in the name of liberty?

In this chapter, this debate will be framed as the tension between efficiency and accountability within a constitutional system. The classic republican model of the American framers relied on accountability-enhancing mechanisms to divide power in order to check it. These mechanisms maintain separations in offices or functions, and strengthen external checks upon actors in the system. On the other hand, efficiency-enhancing mechanisms are more pragmatic and accommodationist; these tend to blur lines of separation in order to make divided government more fluid, streamlined, and more workable. ${ }^{10}$

Efficiency-enhancing mechanisms are well-known to us. Political parties, by binding Congress and the President to a shared set of policy goals, can stimulate coordination across the branches. (Party's binding effect can completely trump structural divides: the U.S. Senate's preferences may be better predicted, for example, by ideology than by being a branch opposite the President. ${ }^{11}$ ) "Legislative" powers held by the President are another example. Certain constitutions allow the President the faculty of proposing laws, drafting the budget, bringing bills before Congress, fast-tracking legislation, and so on, which can add speed and urgency to the process. Other presidential powers can be applied in such a way as to help speed along the business of legislation. The appointment power, for example, can be used to reward the President's backers with desirable positions inside the public bureaucracy, which can help bring both public administration and the legislature into line with her preferences. The President can also use his financial resources to spearhead pork barrel, lavishing local constituents with spending meant to earn their gratitude and, in turn, that of individual legislators who can help pass the president's legislative agenda.

Although the U.S. Constitution remains a fairly classical example of a "separated system" of powers, over the world, more recent presidential democracies tend to depart from the classical blueprint. ${ }^{12}$ Pragmatic in their arrangements, they tend to eschew strict separations between the branches, and to cluster more proactive power in

\footnotetext{
${ }^{9}$ EDLING, Max M. A Revolution in Favor of Government: Origins of the U.S. Constitution and the Making of an American State. New York: Oxford University Press, 2003 (characterizing the U.S. Constitution as a "revolution in favor" of a strong central government).

${ }^{10}$ This is not to conflate the separation of powers with the separation of functions.

${ }^{11}$ On this point, see LEVINSON, Daryl J.; PILDES, Richard H. Separation of Parties, Not Powers. Harvard Law Review, Cambridge, 2006. Available at SSRN: <https://ssrn.com/abstract=890105>.

12 JONES, Charles O. The Presidency in a Separated System. Washington, D.C.: Brookings Institution, 1994) (classifying the U.S. as, not presidential, but a "separated system" of powers).
} 
the Presidency itself. ${ }^{13}$ (Latin American constitutions are also more heavily presidential because of a long post-independence history of strong centralist governments. ${ }^{14}$ ) In the classical U.S. model, the President has no formal lawmaking powers other than the veto. Brazil, on the other hand, typifies the Latin American ideal of a strong president with a central role in governance and strong proactive powers to initiate legislation.

Drafted in the shadow of military dictatorship, it was a surprise for many that the Brazilian Constitution turned out to be a "more transformative than conservative" text. ${ }^{15}$ The military government had agreed to a democratic transition only on the condition that, rather than electing a constitutional assembly, the Constitution would be drafted by congressional incumbents (largely center-right and pro-military). (This condition also substantially dragged out the process, as legislators were forced to do double duty drafting the constitution in the morning and statutes in the afternoon). In the constitutional Assembly, however, a surprising number of progressive initiatives like the referendum and plebiscite, as well as new social and collective rights, had made their way into the text, thanks to forceful progressive leadership and fractures among the conservative delegation.

One progressive stance which did not carry the day was the left's attempt to rid Brazil of its presidential system. For the left, this position was a reaction, not just to the brutal excesses of the military junta, first nurtured by, then cannibalizing, the executive branch, but also to lessons learned from democracy's collapse in 1964, which many blamed on paralysis characteristic of that system. ${ }^{16}$ But despite progressives' successes in the Assembly to that point, Brazilian presidentialism was saved at the eleventh hour

\footnotetext{
${ }^{13}$ KATZ, Andrea S. The President in His Labyrinth: Checks and Balances in the New Pan-American Presidentialism. New Haven, 2016. Dissertation (Ph.D.). Yale University (arguing that more recent presidential democracies, especially those of Latin America, are more president-centric and less structurally "separate").

${ }^{14}$ GARGARELLA, Roberto. The Legal Foundations of Inequality. New York: Cambridge University Press, 2010.

${ }^{15}$ PILATTI, Adriano. A Constituinte de 1987-1988: progressistas, conservadores, ordem econômica e regras do jogo. Rio de Janeiro: Lúmen Júris, 2008, p. 5. This section relies, in addition to Pilatti, on the following accounts of the history of the Constitutional Convention: ROSENN, Keith S., Conflict Resolution and Constitutionalism: The Making of the Brazilian Constitution of 1988. In: MILLER, Laurel E. (ed.). Framing the State in Times of Transition: Case Studies in Constitution Making. Washington, D.C.: U.S. Institute of Peace, 2010, p. 435-466; MAINWARING, Scott; PÉREZ-LIÑAN, Aníbal. Party Discipline in the Brazilian Constitutional Congress. Legislative Studies Quarterly, vol. 22, no. 4, 453-483, 1997; AMES, Barry; POWER, Timothy. Research Guide to Roll-Call Voting in Brazil's Constituent Assembly, 1987-1988. Unpublished manuscript, 1990.; BONAVIDES, Paulo; ANDRADE, Paes de. História Constitucional do Brasil. Brasília: Senado Federal, 1989; BRASIL. Câmara dos Deputados, Diários da Assembléia Nacional Constituinte. Brasília: Câmara dos Deputados, Coordenação de Publicações, 1987; COELHO, João Gilberto; OLIVEIRA, Antonio Carlos Nantes de. A nova constituição. Avaliação do texto e perfil dos constituintes. Rio de Janeiro: Revan, 1989; SOUZA, Márcia Texeira, O processo decisório na Constituição de 1988: práticas institucionais. Lua Nova - Revista de Cultura Política, vol. 58, 3859, 2003; and BARBOSA, Leonardo Augusto de Andrade. História Constitucional Brasileira: Mudança constitucional, autoritarismo e democracia no Brasil pós-1964. Brasília: Edições Câmara dos Deputados, 2012.

${ }^{16}$ RENNÓ, Lucio. Críticas ao Presidencialismo de Coalizão no Brasil: Procesos Institucionalmente Constritos ou Individualmente Dirigidos? In: AVRITZER, Leonardo; ANASTASIA, Fátima (eds.). Reforma Política no Brasil. Minas Gerais: Editora UFMG, 2007.
} 
by the "Centrão," a center-right coalition patched together out of squabbling parties on the right loyal to the incumbent, José Sarney, also a favorite of the military.

This was not the last hurrah and the Brazilian parliamentarism, however. Incredibly, one Antônio Henrique Bittencourt da Cunha Bueno, a representative from São Paulo and avowed monarchist, managed to slip into the Constitution a provision triggering a referendum whereby the Brazilian people would have a chance to choose their preferred system of government. Bittencourt considered Brazil's golden age to have been the reign of Emperor Pedro II (1831-1889), and, in the run-up to the 1993 referendum, actively campaigned with the emperor's great-grandson for the monarchical alternative. Alas, it was not to be. Republicanism carried the day over monarchy, with $66 \%$ to $10 \%$ of the vote, respectively, while the second question on the ballot, presidentialism versus parliamentarism, broke in favor of the status quo, $55 \%$ to $24 \%$.

Thus Brazilian presidentialism survived. And although the drafters had succeeded in whittling down some of the president's powers, the Brazilian president is one of the strongest of any nation-on paper, at least. ${ }^{17}$ Fernando Limongi calls the president the "principal legislator" of Brazil. ${ }^{18}$ The President can initiate legislation, and has exclusive authority to introduce bills relating to the following policy areas: administrative or judicial organization, including the creation and abolition of public offices and Ministries; tax and budgetary matters; public services and administrative personnel; the tenure of civil servants; the organization of federal public defender's offices; and the military. Between 1988 and 2007, around $85.6 \%$ of laws approved by Congress were initiated in the executive branch, and $71 \%$ of all bills submitted by the President to Congress were approved within his or her mandate. ${ }^{19}$ With the powerful partial veto in hand, the President also has the ability to shape legislation before it is passed. ${ }^{20}$

\footnotetext{
${ }^{17}$ On the comparative robust powers of the Brazilian president, see, e.g., SHUGART and CAREY, supra n. 9; FIGUEIREDO, Argelina; LIMONGI, Fernando. Executivo e Legislativo na nova ordem constitucional. 2nd ed. Rio de Janeiro: Editora FGV, 2001; POWER, Timothy. The pen is mightier than the Congress: Presidential decree power in Brazil. In: CAREY, John M. and SHUGART, Matthew Soberg (eds.) Executive Decree Authority. New York: Cambridge University Press, 1994, p. 197-230; PRADO, Mariana Mota; PEREIRA, Carlos. Presidential Dominance from a Comparative Perspective: The Relationship between the Executive Branch and Regulatory Agencies in Brazil. In: ROSE-ACKERMAN, Susan; LINDSETH, Peter L. (eds.). Comparative Administrative Law. Cheltenham: Edward Elgar, 2010, p. 239; ALSTON, Lee J.; MUELLER, Bernardo. Pork for Policy: Executive and Legislative Exchange in Brazil. The Journal of Law, Economics, \& Organization, vol. 22, no. 1, p. 87-114, 8788, 2005. p. 87-88; BINENBOJM, Gustavo. Uma Teoria do Direito Administrativo. 3. ed. Rio de Janeiro: Editora Renovar, 2014.

${ }^{18}$ LIMONGI, Fernando. Presidencialismo e Governo de Coalizão. In: AVRITZER, Leonardo; ANASTAIA, Fátima (eds.). Reforma política no Brasil. Minas Gerais: Editora UFMG, 2007, p. 256.

${ }^{19}$ LIMONGI, supra n. 18, p. 256.

${ }^{20}$ INÁCIO, Magna. Estructura y Funcionamiento de la Cámara de Diputados. In: SÁEZ, Manuel Alcántara; MELO, Carlos Ranulfo (eds.), La democracia brasileña: Balance y perspectivas para el siglo XXI. Salamanca: Ediciones Universidad de Salamanca, 2008. p. 159.
} 
The president also has broad power to govern by decree. ${ }^{21}$ Although decretos (decrees) with the force of law from the pre-dictatorship era were replaced by medidas provisórias (provisional measures), valid only for 60 days, after which Congress must pass, amend, or reject them, these are a powerful tool for the sheer reason that they can clog up Congress' agenda, as, if not voted on within 45 days, they skip to the head of the queue, superseding all other legislative deliberations. The President also wields great power as the head of Brazil's enormous thicket of federal agencies, with sole supervisory power over their organization, operation, and "higher management." She can not only fill but also abolish vacant federal government positions, and, with senatorial consent, can appoint not only Cabinet members and federal court judges, but also state Governors, federal public prosecutors, the head of the Central Bank and numerous others, a staggering 48,000 appointments in total. ${ }^{22}$

Yet even the greatest formal powers mean little without, as American presidential scholar Richard Neustadt put it, "the power to persuade."23 In a 2010 interview, former president Cardoso reflected back on the challenges of the office:

The worst mistake presidents can commit is to imagine that they have a mandate to govern alone. In order to fulfill their promises to the electorate, they need Congress. And to obtain a majority in Congress they need to build alliances... Without alliances presidents do not govern.

In modern Brazil, not only legislative productivity but also presidential success and system function require the formation of broad but disciplined and lasting coalitions. ${ }^{24}$ Under Cardoso and Lula, for instance, such coalitions were built up, and startling

\footnotetext{
${ }^{21}$ Constitution of the Federative Republic of Brazil, Arts. 62 and 84, I.

${ }^{22}$ Constitution, Art. 84, XV and XXV.

${ }^{23}$ NEUSTADT, Richard. Presidential Power and the Modern Presidents: The Politics of Leadership From Roosevelt to Reagan. New York: Free Press, 1991. p. 29.

${ }^{24}$ FIGUEIREDO, Argelina Cheibub; LIMONGI, Fernando. Mudança Constitucional, Desempenho do Legislativo e Consolidação Institucional. Revista Brasileira de Ciencias Sociais, vol. 10, no. 29, p. 175-200, 1995; FIGUEIREDO, Argelina Cheibub; LIMONGI, Fernando. Presidential Powers, Legislative Organization, and Party Behavior in Brazil. Comparative Politics, vol. 32, no. 2, 2000, p. 151-170; LIMONGI, Fernando. Democracia no Brasil: presidencialismo, coalizão partidária e processo decisório. Novos Estudos - CEBRAP, vol. 76, p. 17-41, 2006, LEMOS, Leany B.; POWER, Timothy J. Determinantes do controle horizontal em parlamentos reativos: o caso do Brasil (1988-2005). Dados, vol. 56, p. 383-412, 2013; ARMIJO, Leslie Elliott; FAUCHER, Philippe; DEMBINSKA, Magdalena. Compared to What?: Assessing Brazil's Political Institutions. Comparative Political Studies, vol. 39, no. 6, p. 759-786, 2006; NETO, Octávio Amorim; SANTOS, Fabiano G.M. The Executive Connection: Explaining the Puzzles of Party Cohesion in Brazil. Party Politics, vol. 7, no. 2, p. 213-34, 2002; COX, Gary W.; MORGANSTERN, Scott, Latin America's Reactive Assemblies and Proactive Presidents. Comparative Politics, vol. 33, no. 2, p. 171-189, 2001; REICH, Gary, Executive Decree Authority in Brazil: How Reactive Legislators Influence Policy, Legislative Studies Quarterly, vol. 27, no. 1, p. 5-31, 2002; FIGUEIREDO, Argelina. Resenha de estudos sobre o Executivo. Revista do Serviço Público, vol. 55, nos. 1-2, p. 5-48, 2014. Bolivar Lamounier discusses the prolificness of the Cardoso administration, although he considers it "paradoxical" given the system's "manifest dysfunctionality." FIGUEIREDO, Rubens; LAMOUNIER, Bolívar. A era FHC: um balanço. São Paulo: Editora
} 
legislative productivity was the result. On the other hand, for presidents like Fernando Collor de Mello and of course Dilma, taming a fractious, undisciplined Congress proved impossible, and their tenures ended in impeachment.

In the absence of ties that bind President and party, and with Congress fragmented into dozens of parties, coalition-building is no easy task. Even relatively established parties - the center-right PSDB and PMDB, and the leftist PT-are, today, sprawling conglomerates standing for little in the way of a coherent message. Gross malapportionment in Brazil's two congressional houses further complicates matters: in the Senate, the ratio of over-representation between the smallest and largest state stands at about 88:1 (65:1 in the U.S.). Three-quarters of Senate seats and a majority of those the lower house are controlled by Brazil's three poorest and most backward "macro-regions," which account for two-fifths of the population. ${ }^{25}$ The President flaunts the wishes of these staunchly religious and conservative regions at her own peril, as the recent impeachment of Dilma showed.

\section{ACCOUNTABILITY: MECHANISMS OF PRESIDENTIAL OVERSIGHT}

Given the current backdrop of the Petrolão and Lava Jato, it is impossible to talk about Brazil's political branches without discussing the role of judges and prosecutors. In the current crisis, politics has become "judicialized,"26 the legal and the political spheres closely intertwined-too close, many feel. With Brazil's celebrity judges and prosecutors playing God over the fates of the political higher-ups_Lula, Cunha, and Temer just a short list-disillusioned observers see courts and prosecutors as high-handed at best; as hypocritical tools of right-wing interests, at worst.

In the separation-of-powers model, Congress is, in theory, the primary branch for exercising "horizontal accountability"27 over the President. This encompasses two

Saraiva, 2002; LAMOUNIER, Bolívar, Brazil: an assessment of the Cardoso administration. Constructing democratic governance in Latin America, vol. 2, p. 269-291, 2003.

${ }^{25}$ ANDERSON, Perry. Crisis in Brazil. London Review of Books, vol. 38 no. 8, p. 15-22, April 2016, SAMUELS, David; SNYDER, Richard. The Value of a Vote: Malapportionment in Comparative Perspective. British Journal of Political Science, vol. 31, p. 651-71, 2001. p. 662.

${ }^{26}$ ARANTES, Rogério B. Judiciário: entre a Justiça e a Política. In: AVELAR, Lucia; CINTRA, Antonio Octavio (eds.), Sistema Político Brasileiro: uma introdução. 2. ed. Rio de Janeiro: F Konrad Adenauer; Editora UNESP (2007), p. 81-115. For Arantes, the judicialization of politics is most likely to take place when certain conditions are met, as in Brazil, namely, democracy reestablished in the $80 \mathrm{~s}$, a federal constitution with an extensive list of provisions, a growing list of interest groups demanding the resolution of collective problems, a multi-party system requiring coalitions to support the government, use of the judiciary as a tool of opposition to the government, and a constitutional model delegating a high degree of legitimacy to the judiciary in various areas.

${ }^{27}$ LEMOS and POWER, supra n. 24. On Congress' role in holding the President to account, see COX and MORGANSTERN, supra n. 24; MORGANSTERN, Scott; NEGRI, Juan Javier; PÉREZ-LIÑÁN, Aníbal, Parliamentary Opposition in Non-Parliamentary Regimes: Latin America. The Journal of Legislative Studies, vol. 14, no. 1-2, p. 160-189, 2008; BARROSO, Luis Roberto. Brazil's Unbalanced Democracy: Presidential Hegemony, Legislative Fragility and the Rise of Judicial Power. Lecture at Yale Law School, New Haven, CT, 2011. 
types, political and legal accountability: policy agreement is an example of the one; transparency and the absence of crime the other. This, at least, is in theory. In reality, the distinction has collapsed. What tends to drive Congress's exercise of its typical investigative tools - public hearings, summoning ministers for testimony, investigative commissions - are the distinctively non-legal criteria of, one, presidential popularity with the public and, two, the size of the pro-presidential faction in Congress. ${ }^{28}$ Impeachment, rather than a remedy for high "crimes" against the Constitution and the Union, ${ }^{29}$ seems in practice the punishment for political incompetence, as in the cases of Collor and Dilma.

On the judicial side of things, the Brazilian landscape is varied and complicated, but in the context of this chapter, two important features stand out: the strength of Brazil's regional sub-units and the power of courts, and especially public prosecutors. As a federated state, Brazil decentralizes a good deal of power to its states, and wealthy regions like São Paulo and Minas Gerais boast famously strong institutions, especially governors, judges, and prosecutors. This is part of the reason why Lava Jato started on the watch of federal prosecutors from the city of Curitiba.

The commonplace that Lava Jato has "politicized" the Brazilian judiciary is misleading. Under the 1988 Constitution, the Brazilian judiciary was conceived as a political actor-not, of course, in the sense of being a political partisan (political independence and professionalism having always been buzzwords for Brazil's public servants), but in the sense that in post-dictatorship Brazil, courts began to be understood as sites for popular democratic action, especially in the absence of action by often-weak representative institutions. ${ }^{30}$

In the Brazil emerging from the shadow of dictatorship in the mid-' 80 s, a heady spirit of reform demanded more than a passive citizenry that voted once every few years. ${ }^{31}$ As in other relatively young Latin American democracies, new forms of participatory institutions took root in Brazil: some were direct grassroots bodies attempting to shape public law and administration. ${ }^{32}$ New offices sprang up, including the newly

\footnotetext{
${ }^{28}$ LEMOS and POWER, supra n. 24.

${ }^{29}$ Constitution of the Federative Republic of Brazil, Art. 85 (defining impeachment), and Law No. 1.079 of April 10, 1950 (defining crimes for which impeachment is a remedy), available at: http://www.planalto.gov.br/ccivil_03/LEIS/L1079.htm.

${ }^{30}$ VIANNA, Luis Werneck; CARVALHO, Maria Alice Rezende de; MELO, Manuel Palácios Cunha; BORGES, Marcelo Baumann. A Judicialização da Política e das Relações sociais no Brasil. Rio de Janeiro: Editora Revan, 1999, p. 47-70. See also the discussion of "interventionist constitutionalism" (constitucionalismo dirigente) in COSTA, Fernando Magalhães; MAGALHÃES, Frederico. Judicialização da política e ativismo judicial à luz do procedimentalismo e do substancialismo. Conteúdo Jurídico, Brasília, p. 14-16, Sept. 2015.

${ }^{31}$ AVRITZER, Leonardo. Impasses da Democracia no Brasil. Rio de Janeiro: Editora Civilização Brasileira, 2016.

32 Thamy Pogrebinschi has explored these at length in Brazil. POGREBINSCHI, Thamy. Participation as Representation: Democratic Policymaking in Brazil. In: CAMERON, Maxwell A., HERSHBERG, Eric, and SHARPE, Kenneth E. Sharpe (eds.). New Institutions for Participatory Democracy in Latin America. New York: Palgrave Macmillan, 2012), p. 53-74; POGREBINSCHI, Thamy. The Pragmatic Turn of Democracy in Latin America.
} 
powerful Public Prosecutor, ${ }^{33}$ and old institutions like the courts were recast as a sort of "wailing wall" of popular claims, and given new powers. ${ }^{34}$ Prime examples of these the individual constitutional action (ação popular) and the power of public prosecutors to bring public class actions in the name of the people against private enterprises and government actors (ações civiis públicas, ACPs). In the process, the work of public prosecutors became a deeply visible and popular exercise. As one commentator puts it, the proper object of prosecutorial tutelage has gone from narrow private litigated interests to the "public interest" writ large, adding vast new responsibilities, but above all, social meaning, to an old institution. ${ }^{35}$ Another weapon in the prosecutorial toolkit is the termo de ajustamento de conducta (TAC), a kind of plea bargain allowing prosecutors to leverage the mere threat of a lawsuit into behavioral modifications against public and private actors, a device with extremely broad application given how much faster it is than a typical lawsuit. ${ }^{36}$

The ACP and the TAC are important for another reason than the visibility they offer prosecutors: it gives them broad abilities to sue the government, and therefore to shape public policy. ACPs have been filed against hosts of federal agencies, including those that oversee the provision of electricity, water, and oil, those that are responsible for environmental regulation, and even the Ministry of Social Security, accusing it of unreasonable delays in performing medical exams in rural states. In the year before her impeachment, an ACP was filed against President Rousseff herself by the opposition PSDB for her alleged illicit use of public funds to defend herself from impeachment. Meanwhile, thousands of TACs are filed a day in the interests of protecting public property, labor rights, and the environment, and to correct and punish corporate malfeasance. ${ }^{37}$

Friedrich Ebert-Stiftung: Latin America and the Caribbean, p. 3-20, Aug. 2013; POGREBINSCHI, Thamy. The Impact of Participatory Democracy: Evidence from Brazil's National Public Policy Conferences. Comparative Politics, vol. 46, no. 3, p. 313-332, Apr. 2014.

${ }^{33}$ KERCHE, Fábio. Autonomia e discricionariedade do Ministério Público no Brasil. Dados-Revista de Ciências Sociais, vol. 50, no. 2, p. 259-279, 2007.

${ }^{34}$ VIANNA, Luis Werneck; BURGOS, Marcelo Baumann. Entre princípios e regras: cinco estudos de caso de Ação Civil Pública. Dados. vol. 48, n.4, p.777-843, 2005. p. 781. LOPES, José Reinaldo de Lima. Brazilian Courts and Social Rights: A Case Study Revisited. In: GARGARELLA, Roberto, DOMINGO, Pilar, and ROUS, Theunis (eds.). Courts and Social Transformations in New Democracies: An Institutional Voice for the Poor? New York: Routledge, 2016, p. 185-212; ARANTES, Rogério B.; COUTO, Cláudio G. Constitutionalizing Policy: The Brazilian Constitution of 1988 and its Impact on Governance. In: NOLTE, Detlef; SCHILLING-VACAFLOR, Almut (eds.). New Constitutionalism in Latin America. New York: Routledge, 2012.

${ }^{35}$ VIANNA and BURGOS, supra n. 34.

${ }^{36}$ CRAWFORD, Colin. Defending Public Prosecutors and Defining Brazil's Environmental "Public Interest": A Review of Lesley McAllister's Making Law Matter: Environmental Law and Protections in Brazil. George Washington International Law Review, vol. 40, no. 3, p. 619-647, 2009, p. 620.

${ }^{37} \mathrm{TACs}$ also give prosecutors great leverage over the regulatory state. This is particularly so in their role supporting public-private partnerships. For a population wary of privatizations, TACs ensure corporate accountability in these transactions, freeing up the government to contract with such actors without arousing public suspicion. ROSE-ACKERMAN, Susan. Public Administration and Institutions in Latin America. Paper prepared for 
TACs have been used to bring a regional public health agency into compliance with the law by forcing it provide services it had reneged upon, and against clothing manufacturer Zara to impose fines upon it for using unpaid labor in its factories. ${ }^{38}$

It is worth emphasizing the scope of this power. "Try to imagine," writes Colin Crawford, "an arm of the U.S. Department of Justice suing the U.S. President and the administrator of the U.S. Environmental Protection Agency for failing to enforce the environmental laws, and one begins to appreciate the potential scope of the Ministério Público's authority. For most of us, the scenario is unimaginable in the United States." ${ }^{39}$

\section{A BALANCE SHEET FOR COALITIONAL PRESIDENTIALISM}

Historically, there has been vivid disagreement among scholars about how to assess Brazil's coalitional presidentialism. Defenders tout the virtues of moderation and stabilization that coalitional governance supposedly imposes. ${ }^{40}$ On the other hand, for most political scientists, especially those outside of Brazil, the prevailing wisdom is that "modern democracy is unthinkable save in terms of political parties," the opportunism and prodigious appetite of Brazil's "politicians without parties" just proof of the system's immaturity and weakness. ${ }^{41}$

What successful coalition-building actually requires is debated, and the answer is necessarily bound up with one's assessment of the Brazilian system as a whole. The most rational mechanism, expounded by Octávio Amorim Neto and others, is the "party balance" model. On this theory, a President's need to win support from legislative allies is translated into appointments to top positions in ministries, governmental agencies and public enterprises that mirror the composition of the governing coalition of the moment. As the logic goes, the more proportional the cabinet, the greater chance

Copenhagen Consenso, San José, Costa Rica, Oct. 2007; PIRES, Roberto. Promoting Sustainable Compliance: Styles of Labour Inspection and Compliance Outcomes in Brazil. International Labour Review, vol. 147, nos. 2-3, p. 199-229, Jan. 2008; COSLOVSKY, Salo V.; LOCKE, Richard. Parallel Paths to Enforcement: Private Compliance, Public Regulation, and Labor Standards in the Brazilian Sugar Sector. Politics \& Society, vol. 41, no. 4, p. 497-526, Dec. 2013.

${ }^{38}$ VIANNA and BURGOS, supra n. 34, 786.

LOPES, José Reinaldo de Lima. Brazilian Courts and Social Rights: A Case Study Revisited. In: GARGARELLA, Roberto, DOMINGO, Pilar, and ROUS, Theunis (eds.). Courts and Social Transformations in New Democracies: An Institutional Voice for the Poor? New York: Routledge, 2016, p. 185.

${ }^{39}$ CRAWFORD, supra n. 36, p. 621.

${ }^{40}$ See note 24 , supra.

${ }^{41}$ AMES 1995, supra n. 3, AMES 2002, supra n. 3, MAINWARING, Scott. Politicians, Parties, and Electoral Systems: Brazil in Comparative Perspective. Comparative Politics, vol. 24, no. 1, p. 21-43, Oct. 1991, MAINWARING, Scott. Party Systems in the Third Wave. Journal of Democracy, vol. 9, no. 3, p. 67-81, July 1998; MAINWARING, Scott. Rethinking Party Systems in the Third Wave of Democratization: The Case of Brazil. Palo Alto: Stanford University Press, 1999; SAMUELS, David J. Sources of Mass Partisanship in Brazil. Latin American Politics and Society, vol. 48, no. 2, p. 1-27, Spring 2006; ROBERTS, Kenneth, Changing Course in Latin America: Party Systems in the Neoliberal Era. New York: Cambridge University Press, 2014. 
the President's legislative allies are satisfied with the arrangement, the more disciplined the legislative coalition, and thus the greater chance of presidential success at getting her legislative agenda passed..$^{42}$

Defenders of the partisan balance model find in it many virtues. Wide legislative coalitions are thought to impose moderation and consensus on the executive policy agenda, neutralizing radical sharp turns in policymaking and imposing a kind of discipline on presidential unilateralism. ${ }^{43}$ Coalitions prove fairly stable across administrations, the President's agenda-setting powers allowing her to neutralize personalism and secure disciplined party support. ${ }^{44}$ Patronage also helps stabilize the coalition, providing party leaders with the means to discipline and punish backbenchers. Bargaining need not even take place on a item-by-item basis: once the government is formed and benefits distributed among coalition members, the president may exact support for his or her entire legislative platform much like a prime minister. ${ }^{45}$ Cabinet proportionality is also thought to reduce unilateralism by the President, the rate of decrees going down in direct proportion. ${ }^{46}$

The vividly contrasting tenures of presidents Fernando Collor de Melo (1990-92) and Fernando Henrique Cardoso (1994-2003) speak to the accuracy of partisan balance model. The first popularly elected president in Brazil after the dictatorship, the charismatic young Collor enjoyed strong popular backing early in his tenure, but his radical plan of neoliberal reforms was supported, as one Argentine journalist put it, "only by his

\footnotetext{
${ }^{42}$ NETO, Octavio Amorim. Presidencialismo e Governabilidade nas Américas. Rio de Janeiro: Fundação Getúlio Vargas, 2006, 64-70; NETO, Octavio Amorim. Presidential cabinets, electoral cycles, and coalition discipline in Brazil. In: MORGANSTERN, Scott, and NACIF, Benito (eds.). Legislatures and Democracy in Latin America. New York: Cambridge University Press, 2002, pp. 48-78; NETO and SANTOS, supra n. 24. But see CHEIBUB, José Antonio; LIMONGI, Fernando. Democratic Institutions and Regime Sruvival: Presidentialism and Parliamentarism Reconsidered. Annual Review of Political Science, vol. 5, p. 151-179, 2002 (finding no connection between cabinet proportionality and legislative success of the presidential agenda).

${ }^{43}$ MELO and PEREIRA, supra n. 6. Political scientist Giovanni Sartori's 1997 study of comparative constitutional design focused on the political conditions that could engender "consensus democracy" by balancing the need for strong parliamentary control and efficient government with safeguards against both parliamentary obstructionism and government by decree. SARTORI, Giovanni. Comparative Constitutional Engineering: An Inquiry into Structures, Incentives, and Outcomes. New York: NYU Press, 1997. Observed former president Cardoso in an interview in 2012, "[T]here is a kind of non-explicit agreement [in our system for consensus]. When Lula became President the world believed he would destroy everything that I had done. And he didn't ... When I lived in Chile [during Brazil's period of military dictatorship] the Christian Democrats and Socialists were opponents ... Then they merged to create a united force, the Concertación. We didn't do that. But in practice we are doing the same." Interview with Fernando Henrique Cardoso, "More personal security, less inequality." The Economist Online, Jan. 19, 2012.

${ }^{44}$ MAINWARING, Scott; SHUGART, Matthew S. Presidentialism and Democracy in Latin America. New York: Cambridge University Press, 1997; FIGUEIREDO and LIMONGI, supra n. 24.

${ }^{45}$ The distribution of ministries and high-ranking positions also follows a federalist logic, as the government must cater to factions at different state levels. LIMONGI, supra n. 24, 2005.

${ }^{46}$ NETO, Octavio Amorim; TAFNER, Paulo. Governos de coalizão e mecanismos de alarme de incêndio no controle legislativo das medidas provisórias. Dados, vol. 45, no. 1, p. 5-38, 2002.
} 
arrogance and by the advice of a group of technocrats." ${ }^{17}$ While his predecessor, Sarney, had maintained a flourishing spoils system of patronage, Collor's style of leadership was less consensual and much more technocratic. His initial governing coalition consisted of only three political parties and covered 245 seats, or about 49 percent of the Chamber of Deputies; 60 percent of the posts in his first cabinet went to non-partisan ministers. ${ }^{48}$ Admittedly, the administration was crippled by a perpetually bleak economic forecast of massive hyperinflation, and beset by a series of corruption scandals and massive popular protests around the country. But when Collor was impeached from office in 1992, it was his hubris, unilateralism, and lack of real alliances or strong backing in Congress that were blamed for the fall.

Collor's successor Cardoso, or FHC, as he was popularly known, was never tempted to repeat this experiment in unilateralism. His party, the PSDB, had won a scant 14\% of seats in Congress in 1994 (and would win 17.5\% in 1998). Of necessity, Cardoso stitched together a sprawling legislative coalition totaling, at one time, six parties and $72.8 \%$ of seats in the Chamber of Deputies. ${ }^{49}$ Notwithstanding its size, the coalition was blessed with remarkable "coalescence" 50 and had notable success in bringing about Cardoso's liberal reformist vision of the "necessary state." The roll-out of four direct cash transfer programs, Bolsa Escola (schooling credits), Agente Jovem/Erradicação do Trabalho Infantil (support for families with children), Bolsa Alimentação (distribution of foodstuffs), and Auxílio-gás (cash transfers for gas), allowed simultaneously for a reduction in poverty and a reduction in bureaucratic waste with the elimination of middlemen. that eliminated that helped to universalize welfare coverage while circumventing the bureaucracy, tamping down on clientelism, and decentralizing and streamlining public spending state by expanding municipal responsibilities and fiscal resources. ${ }^{51}$ Decentralizing fiscal resources via formulae for calculating totals to administer to state governments for grant-in-aid programs, FHC further reduced public spending and pork barrel exchanges between legislators and state governors. Cardoso even managed to launch major reforms to the Brazilian Constitution: state monopolies were dismantled, hiring and salary decisions in the public bureaucracy decentralized, and immediate

\footnotetext{
${ }^{47}$ NATANSON, José. La nueva izquierda: Triunfos y derrotas de los gobiernos de Argentina, Brasil, Bolivia, Venezuela, Chile, Uruguay y Ecuador. Buenos Aires: Penguin Random House Group Editorial Argentina, 2008. p. 56.

${ }^{48}$ PEREIRA, Carlos. Brazil's Executive-Legislative Relations under the Dilma Coalition Government. Washington: Brookings Institution, 2010.

${ }^{49}$ LIMONGI, Fernando; FIGUEIREDO, Argelina. Processo orçamentário e comportamento legislativo: emendas individuais, apoio ao Executivo e programas de governo. Dados, vol. 48, p. 737-776, 2005; PEREIRA, supra n. 48, 2.

${ }^{50}$ NETO, supra n. 42.

${ }^{51}$ These programs were joined by the Program for Family Health, the Support Program for Family Agriculture, and Project Alvorada ("Sunrise"), which targeted municipalities with particularly high rates of residents below the poverty line.
} 
presidential reelection was reinstated. While Cardoso's attempts to reform civil service employee pensions and the tax system failed, while his reforms to social security passed only after having lost much of their bite, as two well-known Brazilian political scientists claim, "it would be impossible to claim that the results achieved [by the Cardoso government] were modest." ${ }^{\prime 2}$

On the other hand, the system's defects have never been clearer. For critics of Brazilian coalitional presidentialism, the standard refrain has been that, given the weakness of political parties, the system was predisposed to opportunism, and therefore only ad hoc illegitimate methods like horse trading or, even worse, bribery could hope to hold it together. ${ }^{53}$ In the light of Lava Jato, the above image of Collor, a political incompetent who squandered his chances at coalition-building, and Cardoso, the seasoned negotiator who sustained a coalition for almost eight years at a comparatively low cost, seems too simple. In fact, the real cost of coalitional stability, even for a gifted leader, is much higher.

As Perry Anderson recounts,

[A]lthough the coffers of Cardoso's campaigns were "clean" in the sense of American money politics, where Super PACs buy votes, and his coalition was ideologically unforced, once he was elected neither his objectives nor those of his allies could be achieved without reliance on other methods. Both his vice-president, Marco Maciel, and his most powerful ally in Congress, Antonio Carlos Magalhães, were linchpins of the repressive political order in the north-east - one installed as governor by the dictatorship in Pernambuco, the other in Bahía, after both had supported the destruction of democracy in 1964 - with no intention of altering traditional ways of running it. ACM, as he liked to

\footnotetext{
${ }^{52}$ FIGUEIREDO and LIMONGI, supra n. 49. Constitutional reform in Brazil requires the approval of three-fifths of all members in both the Chamber of Deputies and the Senate in two separate rounds of voting. Moreover, because regulations in the lower chamber allowed any party to call a vote on individual parts of a proposition, the three-fifths quorum had to be achieved on hundreds of different votes. ALSTON and MUELLER, supra n. 17. GAETANI, Francisco; HEREDIA, Blanca. The Political Economy of Civil Service Reform in Brazil: The Cardoso Years. Document prepared for the Red de Gestión y Transparencia del Diálogo Regional de Política del Banco Interamericano de Desarrollo, p. 1-41, Oct. 2002; KOYASU, Akiko. Social Security Reform by the Cardoso Government of Brazil: Challenges and Limitations of Reform Ten Years After 'Democratization'. The Developing Economies, vol. XLII, no. 2, p. 241-261, June 2004. p. 242.

${ }^{53}$ Expressing the view that institutionalized party systems return superior outcomes, see KITSCHELT, Herbert; HAWKINS, Kirk A.; LUNA, Juan Pablo; ROSAS, Guillermo; ZECHMEISTER, Elizabeth J. Latin American Party Systems. New York: Cambridge University Press, 2010; MAINWARING 1998, supra n. 41, MAINWARING 1999, supra n. 41. On the opportunism and appetite for pork of Brazil's politicians, see, e.g., CAVAROZZI, Marcelo; CASULLO, Esperanza. Los partidos políticos en América Latina hoy: consolidación o crisis? In: ABAL MEDINA, Juan Manuel;CAVAROZZI, Marcelo (eds.) El asedio a la política: los partidos latinoamericanos en la era neoliberal. Rosario: Editorial Homo Sapiens, 2003; ALSTON and MUELLER, supra n. 17; AMES 1995, supra n. 3, AMES 2002, supra n. 3, NETO and SANTOS, supra n. 24, ANDERSON, Perry. The Cardoso Legacy. London Review of Books, vol. 24, no. 24, p. 18-22, Dec. 2002; COX and MORGANSTERN, supra n. 24, WEYLAND, Kurt. The Brazilian state in the new democracy, Journal of Interamerican Studies and World Affairs, vol. 39, no. 4, p. 63-94, Winter 1998.
} 
be known, boasted: "I win elections with a bag of money in one hand and a whip in the other."54

Among the "other methods" Cardoso employed were sheer bribery, as when his bid to revise the Constitution ran into opposition from within his own party. For another, Cardoso's stable majority was the product of a pact between his own party, the PSDB, based in the industrialized wealthy south and south-east, and the conservative PFL, whose electorate lay in the rural north-east and north, enclaves of poverty and authoritarianism. Brazil's heavily jerry-rigged electoral map, which overvalues Brazil's poorest, worst educated, most conservative, and least populous regions, effectively eliminates the possibility of such a coalition for a president on the left. As the fate of the PT shows, such parties must go to greater lengths to achieve similar results.

No one doubts that Lula, Brazil's most popular president in decades, had enormous reserves of personal charisma. But it now turns out that his coalition was held together, for at least his first term, by a very unsavory binding agent. Although Lula had been systematically shunned by industry and the center-right media in his first presidential campaigns of 1989, 1994, and 1998, by 2002, he had managed to reassure banks and companies that he would not attack them and coasted to victory with their support and funding. Yet as a newly-elect, he was a legislative orphan, his newcomer PT utterly lacking in connections in Congress, and still regarded as radical.

Upon taking office, Lula and PT higher-ups eschewed what the obvious route of courting the catch-all PMDB, fearing it would prove a drag on their agenda. Instead, the decision was made to protect some semblance of ideological purity and "stitch together a patchwork of backers out of the dense array of smaller parties, without conceding them much foothold in the government, but paying them cash for their support in the chamber by way of a solatium." In practice, the PT was attempting "to compensate for its lack of the kinds of partner with whom Cardoso had enjoyed a natural connubium ... by dispensing a set of material inducements to co-operation at a lower level, and in lesser coinage: monthly wads of money in lieu of major offices of state." ${ }^{155}$ At the time, it may have seemed a venal sin. But Lula barely weathered the mensalão scandal that exploded when this practice was uncovered in 2006, and during his second term in office, Lula made sure to make room for the PMDB in his Cabinet. ${ }^{56}$ Today, of course, Lula is in jail, serving out a twelve-year sentence for corrupção passiva (receipt of bribes) and money laundering.

\footnotetext{
${ }^{54}$ ANDERSON, supra n. 25.

${ }^{55} \mathrm{Ibid}$.

${ }^{56}$ PEREIRA, supra n. 48; PEREIRA, Carlos; POWER, Timothy; RAILE, Eric D. Coalitional Presidentialism and Side Payments: Explaining the Mensalão Scandal in Brazil. Unpublished manuscript, 2008.
} 
Lula's PT successor, Dilma Rousseff, tried the contrary approach at the start of her term, appointing as vice-president a PMDB loyalist who helped rustle up a coalition covering over 60 percent of the Assembly. Yet Dilma never had Lula's charisma or easy touch as a negotiator, and her pact with the center-right remained forced and tenuous. By the time the Petrobras scandal broke in late 2014, rumors of impeachment began, especially when the PT's misdeeds became clear (Dilma herself never was, and still has not been, formally implicated). In July 2015, the PMDB pulled out of the coalition when its head, Eduardo Cunha, himself came under criminal investigation for involvement in the scandal, accusing the PT of "using its machinery to seek the political persecution of those who turn against it," as the aggrieved Cunha put it. The reality was probably the opposite, the kingmaker PMDB smelling blood in the water and seizing the opportunity to install one of their one in the Planalto, the presidential mansion. Dilma responded in October by increasing the PMDB's share of her cabinet. But by December, anti-PT protests surged, and the PMDB refused to protect her-the impeachment process, ironically, was set in motion by Cunha, by then out of office, and signed off on by Temer while the President was out of the country.

Now Temer serves out the remainder of Dilma's term through January 2019, although he too is banned from running for office for campaign violations. As vice-president, escaped impeachment in June 2017 by a single vote from the Supreme Electoral Tribunal, and he remains under criminal investigation for possible involvement in an illegal ethanol purchasing scheme.

The massive public disgust unleashed by the unfolding corruption scandal has done even more to thrust the judiciary into the spotlight. Early in the investigation, scenes of Lava Jato's lead prosecutor, Deltan Dallagnol being accosted in the street by Brazilians shedding tears of gratitude, or of the tenacious federal judge Sérgio Moro honored in a carnival parade with a twenty-foot-doll in his likeness confirmed the visibility of a Public Prosecutor's Office newly aware of its power to tap into, or mobilize, popular energies.

But Lava Jato walks a fine rope. "A 'clean hands' operation can't risk getting its own hands dirty," observes scholar Rogério Arantes, and the investigation, while impressive in its results thus far, is showing signs of being overstretched. ${ }^{57}$ Some charges brought under its auspices have been flimsy, hasty-especially, agrees the legal community, those against Lula himself. The timing of charges seems to coincide a little too neatly with the electoral calendar, leading to accusations of political favoritism. And in the rush to secure convictions, judicial and prosecutorial ethics have been bent: in March 2016, for example, Judge Moro illicitly leaked a wiretapped phone call betwe-

\footnotetext{
${ }^{57}$ OLIVEIRA, André de. "Protagonismo da Justiça deslocou centro gravitacional da democracia brasileira" (Interview with Rogério Arantes). El Pais Brasil, Sept. 24, 2016.
} 
en Lula and Dilma. Many were aghast at this lapse in judgment, but Moro was never sanctioned.

Today, the prosecutor Dallagnol claims Brazilians are stuck in a "bribeocracy" (propinocrácia) whose transgressions still need to be purged. On the other side are disgruntled petistas and politicians afraid of getting caught up in Lava Jato's net railing against a "government of judges" and an unaccountable, voracious "fourth branch."

This impasse is typical of the structure of Brazil's regime: Dallagnol criticizes the opportunistic quid pro quo that has always structured congressional majorities; the "judicialization of politics" shining the unflattering light of publicity upon the ordinary business of the politics, with the judiciary now deciding the fates of those in the system. The timing of Lava Jato owes much to contingency, but it is also due in part to design. ${ }^{58}$

First, given the fragmented party system, Congress is built to survive through ad hoc jockeying. Add to this the heavily conservative bias guaranteed that body by electoral laws, and long-entrenched norms of patronage and patrimonialism that characterize Brazil's legislative and bureaucratic culture, and it becomes difficult to imagine a productive government keeping its hands clean. ${ }^{59}$

Dirty hands alone would be sordid but sustainable - as it has been for most of Brazil's history-were it not for the deeply political role assigned in the new order to Brazilian prosecutors in light of their public-facing democracy-vindicating persona and the responsibility assigned them as constitutional watchdogs.

The outsized role of judges and prosecutors, as I've tried to show, was partly intentional, partly not. The "judicialization of politics" in Latin America was a logical outgrowth of a past of military impunity and institutional weakness, as Brazil's Constitution reflects. But it also reflects a gradual, steady, and largely unchecked increase in the power of these actors in the face of a notoriously unrepresentative, ineffective, corrupt, and passive Congress unable itself to take on the task of ensuring governmental accountability. With Congress so weak, the judiciary has taken on a larger and larger role in the legislative process. The result is to force that process to respond to norms of transparency and rationality that are totally alien to it, from a cultural point of view, and nearly impossible to achieve, for the structural reasons already discussed.

\footnotetext{
${ }^{58}$ Ibid. Political scientist Rogério Arantes spoke of just this phenomenon in a recent interview. "It is curious how [prosecutors and courts] can cause alternation in power, by electoral and non-electoral routes as has occurred in Brazil today, but cannot completely take the place of politics, which has its own logic and which, at least in a democracy, constitutes the most legitimate language and space of representation and government. In any case, this battle between Justice and Politics is inscribed in our institutional design and should be seen as a permanent championship and not just as an isolated match."

${ }^{59}$ ARANTES, Rogério B. The Federal Police and the Ministério Público. In: POWER, Timothy; TAYLOR, Matthew (eds.). Corruption and Democracy in Brazil. 1 ed. Notre Dame: University of Notre Dame Press, 2011, p. 184217. The foundational take on the history of patrimonial norms in Brazilian politics and society is provided by FAORO, Raymundo. Os donos do poder: Formação do patronato político brasileiro. 3. ed. São Paulo, Editora Globo, 2001.
} 
A final casualty of the system is the judiciary itself. Today's Lava Jato backlash is not just the normal swing of the pendulum once a crisis has passed; the worry is that, by becoming so deeply involved in the political process, the judiciary has savaged the distinction between political and legal, and in turn the ideal of "judicial independence," so crucial to its very survival.

\section{IN LAVA JATO'S WAKE: THE SEMI-PRESIDENTIAL TEMPTATION AND LASTING CHANGES?}

Political crisis has a way of making even seemingly preposterous and radical reform proposals more palatable, and after Lava Jato, Brazil's perennial flirtation with parliamentarism, or at least a closely related semi-presidential version, has reemerged. Attesting to the depths of the crisis, it is the current president, Michel Temer, who has floated a proposal to newly reform the Constitution so as to make the nation a semi -presidential democracy. Temer believes the proposal would improve governance and strengthen cooperation between the two branches. Under that system, the President, directly elected by voters, would choose a prime minister to govern alongside him or her, the President acting as head of state; the Prime Minister head of the government. Where relations between Congress and the executive branch broke down, the Prime Minister would be dismissed and the President would nominate a replacement.

So far, the proposal remains at the "test balloon"stage, although it has the approval of Temer cronies in all the major branches (Supreme Court Justice Gilmar Mendes, president of the Senate Eunício Oliveira (PMDB), and president of the Chamber of Deputies Rodrigo Maia (DEM)). In the meantime, two separate reforms at more advanced stages of consideration by Congress include a bid to create a public fund for political campaigns, with all corporate donations prohibited, and a redistricting proposal that would eliminate proportional representation in an attempt to winnow down the number of represented parties to more manageable levels.

All signs suggest that the semi-presidential option will remain a distant dream for Brazil, but even if passed, it would hardly be the catchall fix that some see. Normalizing the formation and collapse of governments, as opposed to the cataclysmic event that is presidential impeachment, where a president loses parliamentary support, would go some way to stabilizing what appears a normal feature of Brazilian politics. ${ }^{60}$ But without great reform to the party system, there is no reason to think that this would

\footnotetext{
${ }^{60}$ Argelina Figueiredo claims that impeachment in Brazil, far from a bug, may instead reflect properly functioning mechanisms of accountability kicking in to rid the system of a corrupt president. FIGUEIREDO, Argelina. The Collor Impeachment and Presidential Government in Brazil. In: LLANOS, Mariana; MARSTEINTREDET, Live (eds.). Presidential Breakdowns in Latin America: Causes and Outcomes of Executive Instability in Developing Democracies. New York: Palgrave Macmillan, 2010, p.112-13, 124.
} 
rationalize Brazil's corrupt politics, produce better governing outcomes, or transform Congress into a true check on the President.

Real reform to the party system, such as would be needed, is unlikely. For a time during and immediately after the "Salad Revolution" and the arrest of Lula, it seemed that Brazil was turning "bi-partisan" on its own, through the formation of broad proand anti-petista coalitions. Since that time, these have dissolved-without the moral legitimacy of opposition, the strong leadership of Lula, or even the opportunism of incumbent funding, the PT's future especially in doubt.

To change the party system through legal means, electoral reform is the place to start, but at the scale currently proposed, these will not effectuate a real transformation. The hold of the old parties in the North, Northeast, and Southeast regions is unlikely to be threatened by the public campaign fund, the elimination of proportional representation, or a threshold on the number of parties in Congress. With the map still gerrymandered, for the foreseeable future, the stalwart PSDB and PMDB will remain fixtures of any coalition not purchased through illicit means, virtually foreclosing all but a center-right coalition in the FHC mold. Lacking channels to translate electoral success into votes, a frustrated Brazilian left may take to attacking the legitimacy of the system itself. The result will be mass discontent of the sort witnessed today.

As concerns the role of the fearsome "fourth branch," there are signs that the tide is already receding. In May 2016, the independent Contraloria Geral was dissolved by executive order and folded in to the new Ministry of Transparency, Supervision, and Control (under presidential supervision). In May 2017, the Lava Jato task force of the Federal Police of Curitiba was reduced and its budget cut drastically. It is possible that Lava Jato will clean up the worst of Brazil's norms of corruption. At the same time, now that Pandora's box has been opened, it seems that the publicity- and oversight-enhancing role of technology will be here to stay. But horse-trading, spoils, and policy incoherence are likely to remain the primary stock in trade of Congress for some time to come.

\section{REFERENCES}

ALSTON, Lee J.; MUELLER, Bernardo. Pork for Policy: Executive and Legislative Exchange in Brazil. The Journal of Law, Economics, \& Organization, vol. 22, no. 1, p. 87-114, 87-88, 2005.

AMES, Barry; POWER, Timothy. Research Guide to Roll-Call Voting in Brazil's Constituent Assembly, 1987-1988. Unpublished manuscript, 1990.

AMES, Barry. Electoral Rules, Constituency Pressures, and Pork Barrel: Bases of Voting in the Brazilian Congress. Journal of Politics, vol. 57, no. 2, p. 324-343, 1995.

AMES, Barry. The Deadlock of Democracy in Brazil. Ann Arbor: University of Michigan Press, 2002. 
ANDERSON, Perry. Crisis in Brazil. London Review of Books, vol. 38 no. 8, p. 15-22, April 2016,. ANDERSON, Perry. The Cardoso Legacy. London Review of Books, vol. 24, no. 24, p. 18-22, Dec. 2002.

ARANTES, Rogério B. Judiciário: entre a Justiça e a Política. In: AVELAR, Lucia; CINTRA, Antonio Octavio (eds.), Sistema Político Brasileiro: uma introdução. 2. ed. Rio de Janeiro: F Konrad Adenauer; Editora UNESP (2007), p. 81-115.

ARANTES, Rogério B. The Federal Police and the Ministério Público. In: POWER, Timothy; TAYLOR, Matthew (eds.). Corruption and Democracy in Brazil. 1 ed. Notre Dame: University of Notre Dame Press, 2011, p. 184-217.

ARANTES, Rogério B.; COUTO, Cláudio G. Constitutionalizing Policy: The Brazilian Constitution of 1988 and its Impact on Governance. In: NOLTE, Detlef; SCHILLING-VACAFLOR, Almut (eds.). New Constitutionalism in Latin America. New York: Routledge, 2012.

ARMIJO, Leslie Elliott; FAUCHER, Philippe; DEMBINSKA, Magdalena. Compared to What?: Assessing Brazil's Political Institutions. Comparative Political Studies, vol. 39, no. 6, p. 759-786, 2006.

AVRITZER, Leonardo. Impasses da Democracia no Brasil. Rio de Janeiro: Editora Civilização Brasileira, 2016.

BAILYN, Bernard. The Ideological Origins of the American Revolution. Cambridge, MA: Harvard University Press, 2017.

BARBOSA, Leonardo Augusto de Andrade. História Constitucional Brasileira: Mudança constitucional, autoritarismo e democracia no Brasil pós-1964. Brasília: Edições Câmara dos Deputados, 2012.

BARROSO, Luis Roberto. Brazil's Unbalanced Democracy: Presidential Hegemony, Legislative Fragility and the Rise of Judicial Power. Lecture at Yale Law School, New Haven, CT, 2011.

BAILYN, Bernard. The Ideological Origins of the American Revolution. Cambridge, MA: Harvard University Press, 2017.

BINENBOJM, Gustavo. Uma Teoria do Direito Administrativo. 3. ed. Rio de Janeiro: Editora Renovar, 2014.

BONAVIDES, Paulo; ANDRADE, Paes de. História Constitucional do Brasil. Brasília: Senado Federal, 1989.

BRASIL. Câmara dos Deputados, Diários da Assembléia Nacional Constituinte. Brasília: Câmara dos Deputados, Coordenação de Publicações, 1987.

CAVAROZZI, Marcelo; CASULLO, Esperanza. Los partidos políticos en América Latina hoy: consolidación o crisis? In: ABAL MEDINA, Juan Manuel;CAVAROZZI, Marcelo (eds.) El asedio a la política: los partidos latinoamericanos en la era neoliberal. Rosario: Editorial Homo Sapiens, 2003. 
CHEIBUB, José Antonio; LIMONGI, Fernando. Democratic Institutions and Regime Sruvival: Presidentialism and Parliamentarism Reconsidered. Annual Review of Political Science, vol. 5, p. 151-179, 2002.

COELHO, João Gilberto; OLIVEIRA, Antonio Carlos Nantes de. A nova constituição. Avaliação do texto e perfil dos constituintes. Rio de Janeiro: Revan, 1989.

COSLOVSKY, Salo V.; LOCKE, Richard. Parallel Paths to Enforcement: Private Compliance, Public Regulation, and Labor Standards in the Brazilian Sugar Sector. Politics \& Society, vol. 41, no. 4, p. 497-526, Dec. 2013.

COSTA, Fernando Magalhães; MAGALHÃES, Frederico. Judicialização da política e ativismo judicial à luz do procedimentalismo e do substancialismo. Conteúdo Jurídico, Brasília, p. 14-16, Sept. 2015.

COX, Gary W.; MORGANSTERN, Scott, Latin America's Reactive Assemblies and Proactive Presidents. Comparative Politics, vol. 33, no. 2, p. 171-189, 2001.

COX, Gary. The Efficient Secret. New York: Cambridge University Press, 1987.

CRAWFORD, Colin. Defending Public Prosecutors and Defining Brazil's Environmental "Public Interest": A Review of Lesley McAllister's Making Law Matter: Environmental Law and Protections in Brazil. George Washington International Law Review, vol. 40, no. 3, p. 619-647, 2009.

DESPOSATO, Scott. Party Switching in Brazil: Causes, Effects, and Representation. In: HELLER, William B.; MERSON, Carol (eds.). Political Parties and Legislative Party Switching. New York: Palgrave Macmillan, 2009, p. 109-44.

EDLING, Max M. A Revolution in Favor of Government: Origins of the U.S. Constitution and the Making of an American State. New York: Oxford University Press, 2003.

FAORO, Raymundo. Os donos do poder: Formação do patronato político brasileiro. 3. ed. São Paulo, Editora Globo, 2001.

FIGUEIREDO, Argelina; LIMONGI, Fernando. Executivo e Legislativo na nova ordem constitucional. 2nd ed. Rio de Janeiro: Editora FGV, 2001.

FIGUEIREDO, Argelina Cheibub; LIMONGI, Fernando. Presidential Powers, Legislative Organization, and Party Behavior in Brazil. Comparative Politics, vol. 32, no. 2, 2000, p. 151-170.

FIGUEIREDO, Argelina Cheibub; LIMONGI, Fernando. Mudança Constitucional, Desempenho do Legislativo e Consolidação Institucional. Revista Brasileira de Ciencias Sociais, vol. 10, no. 29, p. 175-200, 1995.

FIGUEIREDO, Argelina. Resenha de estudos sobre o Executivo. Revista do Serviço Público, vol. 55, nos. 1-2, p. 5-48, 2014. 
FIGUEIREDO, Argelina. The Collor Impeachment and Presidential Government in Brazil. In: LLANOS, Mariana; MARSTEINTREDET, Live (eds.). Presidential Breakdowns in Latin America: Causes and Outcomes of Executive Instability in Developing Democracies. New York: Palgrave Macmillan, 2010, p. 111-127.

FIGUEIREDO, Rubens; LAMOUNIER, Bolívar. A era FHC: um balanço. São Paulo: Editora Saraiva, 2002.

GAETANI, Francisco; HEREDIA, Blanca. The Political Economy of Civil Service Reform in Brazil: The Cardoso Years. Document prepared for the Red de Gestión y Transparencia del Diálogo Regional de Política del Banco Interamericano de Desarrollo, p. 1-41, Oct. 2002.

GARGARELLA, Roberto. The Legal Foundations of Inequality. New York: Cambridge University Press, 2010.

INÁCIO, Magna. Estructura y Funcionamiento de la Cámara de Diputados. In: SÁEZ, Manuel Alcántara; MELO, Carlos Ranulfo (eds.), La democracia brasileña: Balance y perspectivas para el siglo XXI. Salamanca: Ediciones Universidad de Salamanca, 2008.

JONES, Charles O. The Presidency in a Separated System. Washington, D.C.: Brookings Institution, 1994.

KATZ, Andrea S. The President in His Labyrinth: Checks and Balances in the New Pan-American Presidentialism. New Haven, 2016. Dissertation (Ph.D.). Yale University.

KELLY, Scott. The slow death of the 'Efficient Secret': The Rise of MP independence, its causes and its implications. London: The Constitution Society, 2014.

KERCHE, Fábio. Autonomia e discricionariedade do Ministério Público no Brasil. Dados - Revista de Ciências Sociais, vol. 50, no. 2, p. 259-279, 2007.

KITSCHELT, Herbert; HAWKINS, Kirk A.; LUNA, Juan Pablo; ROSAS, Guillermo; ZECHMEISTER, Elizabeth J. Latin American Party Systems. New York: Cambridge University Press, 2010.

KOYASU, Akiko. Social Security Reform by the Cardoso Government of Brazil: Challenges and Limitations of Reform Ten Years After 'Democratization'. The Developing Economies, vol. XLII, no. 2, p. 241-261, June 2004.

LAMOUNIER, Bolívar. Brazil: an assessment of the Cardoso administration. Constructing democratic governance in Latin America, vol. 2, p. 269-291, 2003.

LEMOS, Leany B.; POWER, Timothy J. Determinantes do controle horizontal em parlamentos reativos: o caso do Brasil (1988-2005). Dados, vol. 56, p. 383-412, 2013.

LEVINSON, Daryl J.; PILDES, Richard H. Separation of Parties, Not Powers. Harvard Law Review, Cambridge, 2006. Available at SSRN: <https://ssrn.com/abstract=890105>. 
LIMONGI, Fernando; FIGUEIREDO, Argelina. Processo orçamentário e comportamento legislativo: emendas individuais, apoio ao Executivo e programas de governo. Dados, vol. 48, p. 737-776, 2005.

LIMONGI, Fernando. Democracia no Brasil: presidencialismo, coalizão partidária e processo decisório. Novos Estudos - CEBRAP, vol. 76, p. 17-41, 2006.

LIMONGI, Fernando. Presidencialismo e Governo de Coalizão. In: AVRITZER, Leonardo; ANASTAIA, Fátima (eds.). Reforma política no Brasil. Minas Gerais: Editora UFMG, 2007, p. 237-268.

LOPES, José Reinaldo de Lima. Brazilian Courts and Social Rights: A Case Study Revisited. In: GARGARELLA, Roberto, DOMINGO, Pilar, and ROUS, Theunis (eds.). Courts and Social Transformations in New Democracies: An Institutional Voice for the Poor? New York: Routledge, 2016, p. 185-212.

MAINWARING, Scott; PÉREZ-LIÑAN, Aníbal. Party Discipline in the Brazilian Constitutional Congress. Legislative Studies Quarterly, vol. 22, no. 4, 453-483, 1997.

MAINWARING, Scott; SHUGART, Matthew S. Presidentialism and Democracy in Latin America. New York: Cambridge University Press, 1997.

MAINWARING, Scott. Rethinking Party Systems in the Third Wave of Democratization: The Case of Brazil. Palo Alto: Stanford University Press, 1999.

MAINWARING, Scott. Party Systems in the Third Wave. Journal of Democracy, vol. 9, no. 3, p. 6781 , July 1998.

MAINWARING, Scott. Politicians, Parties, and Electoral Systems: Brazil in Comparative Perspective. Comparative Politics, vol. 24, no. 1, p. 21-43, Oct. 1991.

MELO, Marcus André; PEREIRA, Carlos. Making Brazil Work: Checking the President in a Multiparty System. New York: Palgrave Macmillan, 2013.

MORGANSTERN, Scott; NEGRI, Juan Javier; PÉREZ-LIÑÁN, Aníbal, Parliamentary Opposition in Non-Parliamentary Regimes: Latin America. The Journal of Legislative Studies, vol. 14, no. 1-2, p. 160-189, 2008.

NATANSON, José. La nueva izquierda: Triunfos y derrotas de los gobiernos de Argentina, Brasil, Bolivia, Venezuela, Chile, Uruguay y Ecuador. Buenos Aires: Penguin Random House Group Editorial Argentina, 2008.

NETO, Octávio Amorim; SANTOS, Fabiano G.M. The Executive Connection: Explaining the Puzzles of Party Cohesion in Brazil. Party Politics, vol. 7, no. 2, p. 213-34, 2002.

NETO, Octavio Amorim; TAFNER, Paulo. Governos de coalizão e mecanismos de alarme de incêndio no controle legislativo das medidas provisórias. Dados, vol. 45, no. 1, p. 5-38, 2002. 
NETO, Octavio Amorim. Presidencialismo e Governabilidade nas Américas. Rio de Janeiro: Fundação Getúlio Vargas, 2006.

NETO, Octavio Amorim. Presidential cabinets, electoral cycles, and coalition discipline in Brazil. In: MORGANSTERN, Scott, and NACIF, Benito (eds.). Legislatures and Democracy in Latin America. New York: Cambridge University Press, 2002. pp. 48-78.

NEUSTADT, Richard. Presidential Power and the Modern Presidents: The Politics of Leadership From Roosevelt to Reagan. New York: Free Press, 1991.

PEREIRA, Carlos; POWER, Timothy; RAILE, Eric D. Coalitional Presidentialism and Side Payments: Explaining the Mensalão Scandal in Brazil. Unpublished manuscript, 2008.

PEREIRA, Carlos. Brazil's Executive-Legislative Relations under the Dilma Coalition Government. Washington: Brookings Institution, 2010.

PILATTI, Adriano. A Constituinte de 1987-1988: progressistas, conservadores, ordem econômica e regras do jogo. Rio de Janeiro: Lúmen Júris, 2008.

PIRES, Roberto. Promoting Sustainable Compliance: Styles of Labour Inspection and Compliance Outcomes in Brazil. International Labour Review, vol. 147, nos. 2-3, p. 199-229, Jan. 2008.

POGREBINSCHI, Thamy. Participation as Representation: Democratic Policymaking in Brazil. In: CAMERON, Maxwell A., HERSHBERG, Eric, and SHARPE, Kenneth E. Sharpe (eds.). New Institutions for Participatory Democracy in Latin America. New York: Palgrave Macmillan, 2012, p. 53-74.

POGREBINSCHI, Thamy. The Impact of Participatory Democracy: Evidence from Brazil's National Public Policy Conferences. Comparative Politics, vol. 46, no. 3, p. 313-332, Apr. 2014.

POGREBINSCHI, Thamy. The Pragmatic Turn of Democracy in Latin America. Friedrich Ebert-Stiftung: Latin America and the Caribbean, p. 3-20, Aug. 2013.

POWER, Timothy. The pen is mightier than the Congress: Presidential decree power in Brazil. In: CAREY, John M. and SHUGART, Matthew Soberg (eds.) Executive Decree Authority. New York: Cambridge University Press, 1994, p. 197-230.

PRADO, Mariana Mota; PEREIRA, Carlos. Presidential Dominance from a Comparative Perspective: The Relationship between the Executive Branch and Regulatory Agencies in Brazil. In: ROSE-ACKERMAN, Susan; LINDSETH, Peter L. (eds.). Comparative Administrative Law. Cheltenham: Edward Elgar, 2010, p. 225-242.

REICH, Gary. Executive Decree Authority in Brazil: How Reactive Legislators Influence Policy, Legislative Studies Quarterly, vol. 27, no. 1, p. 5-31, 2002.

RENNÓ, Lucio. Críticas ao Presidencialismo de Coalizão no Brasil: Procesos Institucionalmente Constritos ou Individualmente Dirigidos? In: AVRITZER, Leonardo; ANASTASIA, Fátima (eds.). Reforma Política no Brasil. Minas Gerais: Editora UFMG, 2007. 
ROBERTS, Kenneth, Changing Course in Latin America: Party Systems in the Neoliberal Era. New York: Cambridge University Press, 2014.

ROSE-ACKERMAN, Susan. Public Administration and Institutions in Latin America. Paper prepared for Copenhagen Consenso, San José, Costa Rica, Oct. 2007.

ROSENN, Keith S., Conflict Resolution and Constitutionalism: The Making of the Brazilian Constitution of 1988. In MILLER, Laurel E. (ed.). Framing the State in Times of Transition: Case Studies in Constitution Making. Washington, D.C.: U.S. Institute of Peace, 2010, p. 435-466.

SAMUELS, David J. Sources of Mass Partisanship in Brazil. Latin American Politics and Society, vol. 48, no. 2, p. 1-27, Spring 2006.

SAMUELS, David; SNYDER, Richard. The Value of a Vote: Malapportionment in Comparative Perspective. British Journal of Political Science, vol. 31, p. 651-71, 2001.

SARTORI, Giovanni. Comparative Constitutional Engineering: An Inquiry into Structures, Incentives, and Outcomes. New York: NYU Press, 1997.

SOUZA, Márcia Texeira, O processo decisório na Constituição de 1988: práticas institucionais. Lua Nova - Revista de Cultura Política, vol. 58, 38-59, 2003.

VIANNA, Luis Werneck; BURGOS, Marcelo Baumann. Entre princípios e regras: cinco estudos de caso de Ação Civil Pública. Dados. vol. 48, n.4, p.777-843, 2005.

VIANNA, Luis Werneck; CARVALHO, Maria Alice Rezende de; MELO, Manuel Palácios Cunha; BORGES, Marcelo Baumann. A Judicialização da Política e das Relações sociais no Brasil. Rio de Janeiro: Editora Revan, 1999, p. 47-70.

WEYLAND, Kurt. The Brazilian state in the new democracy, Journal of Interamerican Studies and World Affairs, vol. 39, no. 4, p. 63-94, Winter 1998.

WOOD, Gordon S. The Creation of the American Republic, 1776-1787. Chapel Hill, NC: University of North Carolina Press, 1998. 